Berkala Ilmu Perpustakaan dan Informasi, Vol. 13, No. 1, Juni 2017, Hal. 47-55 DOI: http://10.22146/bip.16757

ISSN 1693-7740 (Print), ISSN 2477-0361 (Online)

Tersedia online di https://jurnal.ugm.ac.id/bip

\title{
KEPUASAN PEMUSTAKA TERHADAP FASILITAS PERPUSTAKAAN DI FAKULTAS PSIKOLOGI UNIVERSITAS GADJAH MADA
}

\author{
Pergola Irianti ${ }^{1}$ \\ 'Pustakawan Universitas Gadjah Mada \\ e-mail: pergola_irianti@ugm.ac.id
}

Naskah diterima: 4 April 2017, direvisi: 9 Mei 2017, disetujui: 12 Juni 2017

\begin{abstract}
ABSTRAK
Kajian ini bertujuan untuk mengetahui tingkat kepuasan pemustaka terhadap fasilitas yang tersedia di Perpustakaan Fakultas Psikologi, Universitas Gadjah Mada (UGM). Kajian kuantitatif deskriptif ini populasinya adalah pemustaka di Fakultas Psikologi periode Agustus-Oktober 2016, dengan sampel sebanyak 174 orang. Metode pengumpulan data menggunakan angket, untuk mengetahui kepuasan pemustaka terhadap fasilitas perpustakaan di Fakultas Psikologi UGM. Variabel kepuasan pemustaka difokuskan pada lima indikator, yaitu: koleksi, layanan, teknologi informasi, sumber daya manusia, dan sarana prasarana. Pengukuran masing-masing indikator dengan menggunakan analisis univariat. Hasilnya menunjukkan bahwa: (a) Pemustaka wanita lebih tinggi persentasenya $(79,88 \%)$ daripada pria $(20,12 \%)$, mahasiswa program studi sarjana persentasenya tertinggi $(64,94 \%)$ di antara program studi yang lain, dan sebagian besar dari mereka $(53,44 \%)$ sudah menempuh studi dalam rentang 1-4 semester. (b) Kepuasan pemustaka terhadap fasilitas yang tersedia di perpustakaan Fakultas Psikologi UGM rata-rata nilai skornya sebesar 74,38\% termasuk dalam kategori sangat memuaskan.
\end{abstract}

Kata kunci: kepuasan pemustaka, fasilitas perpustakaan, perpustakaan perguruan tinggi

\section{ABSTRACT}

This study aims to determine the level of user satisfaction on the facilities available at the library of the Faculty of Psychology, Universitas Gadjah Mada (UGM). This descriptive quantitative study focused on 174 library users at the Faculty of Psychology of the period from August to October 2016. The data collection method used questionnaires, in order to determine the user satisfaction of the library facilities. Variables of library user satisfaction covered five indicators: collection, services, information technology, human resources, and infrastructure. Measurement of each indicator was conducted by using univariate analysis. The results showed that: (1) There were more female library users (79.88\%) than males (20.12\%), users with undergraduate level showed the highest percentage (64.94\%), and most of them (53.44\%) were in their first to fourth semester. (2) User satisfaction on the facilities at the library showed $74.38 \%$, and this was included in the category of very satisfactory.

Keywords: user satisfaction, library facilities, college library

\section{A. PENDAHULUAN}

Pada prinsipnya, sebuah institusi pendidikan tinggi memfasilitasi dan melengkapi diri dengan berbagai unsur penunjang untuk proses pembelajaran. Salah satu unsur tersebut adalah perpustakaan, yang dibutuhkan oleh sivitas akademika untuk pemenuhan kebutuhan informasi.
Seperti dikemukakan oleh Sutarno (2005) bahwa kebutuhan sivitas akademika terhadap perpustakaan antara lain untuk menunjang kegiatan pembelajaran.

Perpustakaan perguruan tinggi setidaknya mendukung program tri dharma perguruan tinggi, yaitu pendidikan, penelitian, dan pengabdian kepada masyarakat. Menjaga eksistensi dalam menjalankan 
peran, tugas dan fungsinya, perpustakaan berupaya melakukan pembinaan dan pengembangan aspekaspek perpustakaan. Menurut Sutarno (2005), aspek-aspek yang perlu diperhatikan dalam pembinaan dan pengembangan perpustakaan antara lain: koleksi sebagai sumber informasi, sarana dan prasarana sebagai pendukung aktivitas perpustakaan, anggaran biaya yang memadai, ketenagaan atau sumber daya manusia, dan penerapan teknologi informasi.

Menurut Standar Nasional Indonesia bidang perpustakaan dan kepustakawanan (Perpusnas, 2011), tercantum beberapa aspek perpustakaan antara lain koleksi, sumber daya manusia, layanan perpustakaan, gedung, anggaran, dan teknologi informasi. Masing-masing aspek wajib dipenuhi oleh perpustakaan dalam lingkup perguruan tinggi.

Berdasarkan uraian di atas, aspek-aspek perpustakaan setidaknya mencakup: koleksi, sarana prasarana, anggaran biaya, sumber daya manusia, teknologi informasi, layanan perpustakaan, dan anggaran.

Perpustakaan di Fakultas Psikologi UGM sebagai salah satu bagian sarana dan prasarana pendukung proses pembelajaran, sejak awal pendirian Fakultas Psikologi UGM sampai saat ini konsisten menyediakan kebutuhan pemustaka terutama bagi sivitas akademika dalam lingkup internal. Fasilitas perpustakaan senantiasa diupayakan untuk meningkatkan layanan yang lebih baik kepada pemustaka.

Pada saat ini ada lima program studi yang diselenggarakan oleh Fakultas Psikologi UGM, yaitu program studi sarjana psikologi, program studi pasca sarjana magister sain psikologi dan magister profesi psikologi, program studi doktor psikologi, dan satu lagi yang masih baru yakni program studi sarjana psikologi internasional atau IUP (International Undergraduate Program). Keempat program yang lama, semuanya telah terakreditasi dengan nilai A sejak tahun 2015 (Fakultas Psikologi UGM, 2016). Hal ini tidak terlepas dari penyediaan dan pengelolaan sarana prasarana memadai yang disediakan oleh fakultas untuk tercapainya nilai akreditasi.

Penentuan nilai akreditasi sebuah perguruan tinggi berfokus pada asesmen lapangan yang meliputi tujuh standar. Standar yang erat kaitannya dengan sarana dan prasarana tercantum dalam standar ke enam mengenai: pembiayaan, sarana dan prasarana, serta sistem informasi (Badan Akreditasi Nasional, 2011). Di dalam standar enam ada beberapa elemen yang digunakan dalam penilaian akreditasi, salah satunya penilaian terhadap bahan pustaka yang digunakan dalam proses pembelajaran. Penyediaan dan pengelolaan bahan pustaka yang dilakukan di perpustakaan, menjadikan perpustakaan berperan terhadap hasil asesmen.

Berdasarkan uraian di atas diasumsikan bahwa perpustakaan juga mempunyai peran dalam pencapaian nilai akreditasi A yang telah diraih oleh empat program studi di Fakultas Psikologi UGM sejak tahun 2015. Permasalahan yang timbul dari pernyataan tersebut, apakah pemustaka dalam hal ini mahasiswa juga merasa puas dengan peran perpustakaan sebagai salah satu sarana pendukung dalam proses pembelajaran di Fakultas Psikologi UGM. Selanjutnya pertanyaan yang diajukan dalam kajian ini, yaitu: bagaimana kepuasan pemustaka terhadap fasilitas yang tersedia di perpustakaan Fakultas Psikologi UGM.

Tujuannya untuk mengetahui kepuasan pemustaka terhadap fasilitas yang tersedia di perpustakaan Fakultas Psikologi UGM.

Manfaat yang diharapkan dari hasil kajian yaitu sebagai bahan evaluasi terkait dengan penyediaan fasilitas perpustakaan Dengan demikian dapat digunakan sebagai bahan pertimbangan untuk pengembangan perpustakaan di masa yang akan datang.

\section{B. TINJAUAN PUSTAKA}

Kajian kepuasan pemustaka di Indonesia pernah dilakukan oleh Wijaya (2015) mengenai evaluasi kepuasan pemustaka terhadap pelayanan di perpustakaan umum daerah Tabanan. Dalam kajian tersebut ditemukan bahwa koleksi, sumber daya manusia, fasilitas, akses informasi, serta layanan, rata-rata kepuasannya sebesar 74,2\%. Kajian sebelumnya dilakukan oleh Dharma (2013) mengenai kualitas layanan dan kepuasan pemustaka, hasilnya menunjukkan bahwa ada hubungan antara kualitas layanan dengan kepuasan pemustaka. Nursiah (2008) melakukan kajian mengenai pengaruh kualitas pelayanan terhadap mahasiswa pemustaka di Perpustakaan Politeknik Negeri Medan. Dalam kajian tersebut ditemukan bahwa kualitas pelayanan berpengaruh positif dan signifikan terhadap kepuasan pemustaka, dan dimensi bukti fisik mempunyai pengaruh yang dominan terhadap kepuasan pemustaka.

Kajian di mancanegara pernah dilakukan oleh Deo (2016) mengenai kepuasan pemustaka di perpustakaan fakultas, studi kasus pada Fiji National University. Pada tahun 2012 Larson dan Owusu- 
Acheaw melakukan kajian kepuasan mahasiswa tingkat sarjana terhadap perpustakaan, dan ditemukan bahwa mahasiswa merasa puas dengan layanan yang ada di perpustakaan tersebut. Pada tahun yang sama Ezeala dan Yusuff (2011) melakukan kajian mengenai kepuasan pemustaka terhadap sumber daya dan layanan di perpustakaan Nigerian Agricultural Research Institutes.

\section{Perpustakaan Perguruan Tinggi}

Perpustakaan merupakan salah satu lembaga ilmiah dengan tugas pokok berkaitan dengan ilmu pengetahuan, pendidikan, dan penelitian. Ruang lingkupnya mengelola informasi berbagai ilmu pengetahuan dan informasi (Sutarno, 2005). Perpustakaan perguruan tinggi merupakan salah satu sarana prasarana pendukung pelaksanaan tri dharma perguruan tinggi (pendidikan, penelitian dan pengabdian masyarakat). Menurut Sulistyo-Basuki (1991), penyelenggaraan perpustakaan perguruan tinggi antara lain bertujuan untuk pemenuhan kebutuhan informasi sivitas akademika untuk semua jenjang studi yang diselenggarakan, menyediakan ruang belajar, serta menyediakan jasa peminjaman kepada pemustaka.

Simpulan pengertian perpustakaan perguruan tinggi berdasarkan uraian di atas yakni unit pengelola informasi ilmiah dalam lingkup perguruan tinggi yang menyediakan ruang belajar dan bahan pustaka untuk memenuhi kebutuhan sivitas akademika dalam mendukung program tri dharma perguruan tinggi.

\section{Fasilitas Perpustakaan Perguruan Tinggi}

Persaingan ketat pada era globalisasi, menuntut perpustakaan memiliki kompetensi yang tinggi dengan menunjukkan kemampuan, kesanggupan, dan kinerja berkualitas yang sebenarnya. Menurut Sutarno (2005), perwujudan kompetensi perpustakaan meliputi: (a) penguasaan pengetahuan dan profesionalitas petugas perpustakaan, (b) kelengkapan sumber informasi, (c) kelengkapan sarana prasarana, (d) pemanfaatan secara optimal sumber daya yang ada di perpustakaan.

Menurut Standar Nasional Indonesia bidang kepustakawanan (Perpusnas, 2011), beberapa hal yang harus diperhatikan dalam penyelenggaraan perpustakaan perguruan tinggi, antara lain: koleksi (termasuk pengorganisasian dan pelestariannya), sumber daya manusia, layanan, gedung, anggaran, teknologi informasi dan komunikasi, serta kerjasama perpustakaan.
Berdasarkan uraian di atas dapat disimpulkan bahwa fasilitas utama perpustakaan perguruan tinggi setidaknya meliputi: koleksi, sumber daya manusia, layanan, teknologi informasi dan komunikasi, kelengkapan sarana prasarana, serta anggaran.

Koleksi perpustakaan perguruan tinggi mencakup semua bahan pustaka bidang keilmuan yang diselenggarakan, dengan kriteria pengembangan antara lain: relevan, berorientasi pada kebutuhan sivitas akademika, mutakhir, lengkap dengan bidang ilmu lain sebagai pendukung. Menurut Rahayuningsih (2015) kriteria di atas merupakan salah satu aspek ketersediaan informasi yang berkualitas.

Sumber informasi di perpustakaan perlu pengelolaan dan pendayagunaan sedemikian rupa agar mudah ditemukan kembali dan bermanfaat untuk pemustaka. Oleh karena itu dibutuhkan sumber daya manusia untuk melakukan kegiatan tersebut. Sumber daya manusia memiliki peran penting dalam setiap kegiatan perpustakaan termasuk dalam pencapaian tujuan. Menurut Maryadi dan Widodo (2010) dalam era globalisasi saat ini sumber daya manusia harus aktif dan produktif atau dengan kata lain sumber daya manusia harus berkualitas.

Kualitas sumber daya manusia di perpustakaan ditentukan oleh beberapa aspek layanan yang dapat memberi kepuasan kepada pemustaka. Menurut Rahayuningsih (2015), aspekaspek tersebut antara lain: (a) peduli dan perhatian, (b) cepat tanggap, (c) berpengetahuan dan berwawasan serta mampu dan ramah dalam melayani pemustaka, (d) mampu memberikan janji dan harapan dengan hasil yang tepat dan akurat.

Layanan perpustakaan perguruan tinggi menurut Standar Nasional Indonesia 7330-2009 (Perpusnas, 2011), meliputi: jam buka perpustakaan dan layanan (sirkulasi, pinjam antar perpustakaan, referensi, pendidikan pemustaka/literasi informasi, penelusuran informasi). Di samping beberapa layanan tersebut di atas, Rahayuningsih (2015) menambahkan layanan yang lain, seperti layanan locker, fotokopi, jurnal, dan jumlah maksimum koleksi dipinjam.

Adopsi terhadap teknologi informasi dan komunikasi perlu dilakukan perpustakaan perguruan tinggi untuk mendukung seluruh proses pengolahan dan layanan bahan perpustakaan. Penerapan sistem informasi yang disesuaikan dengan kebutuhan dan dilengkapi dengan perangkat keras dan perangkat lunak yang memadai menjamin kelancaran tugas perpustakaan sebagai sarana pendukung proses pembelajaran di perguruan tinggi (Perpusnas, 2011). 
Penggunaan fasilitas perpustakaan harus memberikan rasa aman dan nyaman bagi pemustaka. Menurut Rahayuningsih (2015), kenyamanan pemustaka ditentukan oleh infrastruktur dan lingkungan kerja perpustakaan. Infrastruktur dan lingkungan kerja tersebut harus memenuhi aspekaspek: tangibles, utilitarian space, symbol term, dan refuge. Penjabaran aspek-aspek tersebut, yaitu: penampilan nyata perpustakaan berupa gedung atau ruang dan peruntukan masing-masing ruang, terbuka untuk pemustaka dan menumbuhkan daya kreativitas, pemustaka merasa tenang ketika belajar atau beraktivitas di perpustakaan.

\section{Kepuasan Pemustaka}

Menurut Snyder dan Lopez (2007) kepuasan merupakan perasaan senang dan bahagia karena adanya kesenjangan yang kecil antara kebutuhan dan harapan. Kotler (2000) mendefinisikan kepuasan konsumen atau kepuasan pemustaka merupakan perasaan seseorang setelah membandingkan kenyataan yang diperoleh dengan harapan sebelumnya. Wilkie (dalam Tjiptono, 1997) mendefinisikan kepuasan pemustaka sebagai tanggapan emosional pada evaluasi terhadap pengalaman penggunaan jasa atau barang.

Berdasarkan uraian di atas dapat disimpulkan bahwa kepuasan merupakan perbandingan perasaan seseorang antara sebelum dan sesudah menerima produk atau jasa. Di sisi lain kepuasan bermanfaat untuk bahan evaluasi bagi penyedia produk atau jasa.

Dalam lingkup perpustakaan, kepuasan pemustaka merupakan faktor yang menentukan keberhasilan perpustakaan (Firman, 2012). Hampir sama dengan pendapat tersebut, Rahayuningsih (2015) mengemukakan bahwa kepuasan pemustaka merupakan pintu gerbang menuju peningkatan keberlanjutan. Ada dua faktor yang mempengaruhi kepuasan pemustaka yakni (a) faktor kasat mata antara lain: kinerja, kualitas, keandalan, dan biaya; (b) faktor tidak kasat mata antara lain: kepedulian, sopan santun, proakif, dan kemampuan pemecahan masalah.

Pada kajian ini kepuasan pemustaka terhadap fasilitas yang tersedia di perpustakaan ditentukan berdasarkan beberapa aspek yang telah diuraikan di atas. Meskipun demikian diutamakan aspek-aspek yang berhubungan langsung dan dapat dirasakan oleh pemustaka. Oleh karena itu pada kajian ini, hanya ada lima aspek yang akan dikaji berkaitan dengan kepuasan pemustaka terhadap fasilitas perpustakaan, yaitu: (1) koleksi, (2) layanan, (3) teknologi informasi, (4) sumber daya manusia, (5) sarana dan prasarana.

\section{METODE PENELITIAN}

Kajian ini merupakan kajian kuantitatif dengan analisis menggunakan metode deskriptif. Populasi dalam kajian ini yaitu pemustaka yang datang dan menggunakan fasilitas perpustakaan di Fakultas Psikologi UGM pada bulan Agustus Oktober 2016, pemustaka yang datang lebih dari satu kali pada tiga bulan tersebut tidak menjadi hitungan populasi. Jumlah pemustaka di Fakultas Psikologi UGM pada bulan Agustus - Oktober 2016 berjumlah 2.885 orang. Pengambilan sampel dilakukan secara incidental sampling, dengan jumlah sampel ditentukan berdasarkan rumus dari Hadi (2002) sebagai berikut:

$$
\mathrm{n}=\mathrm{N} /\left(1+\mathrm{N} \cdot \mathrm{e}^{2}\right)
$$

dengan ketentuan:

$\mathrm{n}=$ jumlah sampel minimal

$\mathrm{N}=$ ukuran populasi

$\mathrm{e}=$ persen kelonggaran ketidaktelitian karena kesalahan pengambilan sampel yang masih ditolerir/diinginkan, misalnya $10 \%$.

Setelah dilakukan perhitungan dengan rumus tersebut diperoleh ukuran sampel sebagai berikut:

$$
\begin{aligned}
\mathrm{n} & =2.885 /\left(1+2.885 \times 0,1^{2}\right)=2.885 / 29,85 \\
& =96.64
\end{aligned}
$$

Berdasarkan perhitungan di atas menunjukkan bahwa jumlah sampel dalam kajian ini sebesar 96,64 dan dibulatkan menjadi 100 responden atau dengan kata lain jumlah minimum yang ditentukan untuk menjadi sampel adalah 100 responden. Pada kajian ini dilakukan penyebaran angket kepada 200 pemustaka yang berkunjung pada tiga bulan tersebut (Agustus - Oktober 2016). Angket terdiri dari tiga bagian, yaitu: identitas, butir pernyataan, dan saran.

Pengumpulan data dalam kajian ini menggunakan angket, yaitu sejumlah pernyataan/pertanyaan tertulis yang digunakan untuk memperoleh informasi dari responden (Arikunto, 2010). Dalam hal ini angket digunakan untuk mengetahui karakteristik pemustaka dan kepuasan pemustaka terhadap fasilitas perpustakaan di Fakultas Psikologi UGM. Variabel karakteristik diperoleh dari data identitas yang dicantumkan 
dalam angket tersebut, meliputi: jenis kelamin, program studi, serta jumlah semester yang sedang ditempuh saat pengambilan data. Variabel kepuasan pemustaka difokuskan pada lima indikator, yaitu: koleksi, layanan, teknologi informasi, sumber daya manusia, dan sarana prasarana. Masing-masing indikator dijabarkan dalam beberapa butir pernyataan.

Masing-masing butir pernyataan disediakan lima pilihan jawaban yaitu: sangat memuaskan, memuaskan, netral, kurang memuaskan, dan tidak memuaskan. Dengan menggunakan skala Likert, masing-masing jawaban diberi nilai sebagai berikut:

$\begin{array}{ll}\text { Sangat Memuaskan } & =5 \\ \text { Memuaskan } & =4 \\ \text { Netral } & =3 \\ \text { Kurang Memuaskan } & =2 \\ \text { Tidak Memuaskan } & =1\end{array}$

Pengukuran masing-masing indikator dengan menggunakan analisis univariat yaitu menghitung skor persentase yang diperoleh dengan rumus: $\mathrm{P}=$ $(\mathrm{fx}) / \mathrm{N}$, dengan ketentuan: $\mathrm{P}=$ hasil skor; $\mathrm{fx}=$ nilai skor diperoleh; $\mathrm{N}=$ nilai ideal keseluruhan butir.

Selanjutnya hasil skor $(\mathrm{P})$ ditentukan kategori penafsirannya sebagai berikut:

$$
\begin{array}{ll}
73,8-100 & =\text { sangat memuaskan } \\
49,2-73,7 & =\text { memuaskan } \\
24,6-49,1 & =\text { kurang memuaskan } \\
0-24,5 & =\text { tidak memuaskan }
\end{array}
$$

Pada bagian akhir dari angket (setelah butir pernyataan), diberikan ruang kosong untuk menuliskan saran. Ini dimaksudkan untuk memberi kesempatan kepada responden mengenai segala sesuatu yang perlu disampaikan ke perpustakaan. Data kualitatif ini kemudian direkap, dan diharapkan bermanfaat untuk menambah saran.

\section{HASIL DAN PEMBAHASAN}

Jumlah angket yang disebarkan selama pengambilan data berjumlah 200 eksemplar, sedangkan jumlah angket yang terkumpul dan dapat dilakukan penghitungan analisis sebanyak 174 angket.

\section{Karakteristik pemustaka}

Hasil kajian berdasarkan karakteristik pemustaka di perpustakaan Fakultas Psikologi UGM dapat dilihat pada Tabel 1 berikut ini
Tabel 1

Sebaran pemustaka di perpustakaan Fakultas Psikologi berdasarkan karakteristik individual

\begin{tabular}{ccc}
\hline Karakteristik individual & Jumlah & $\begin{array}{c}\text { Persentase } \\
(\%)\end{array}$ \\
\hline Jenis kelamin & & \\
\hline Wanita & 139 & 79,88 \\
Pria & 35 & 20,12 \\
\hline Program studi & & \\
\hline S1 & 113 & 64,94 \\
S2 & 61 & 35,06 \\
S3 & 0 & 0 \\
\hline Jumlah semester sedang ditempuh & \\
\hline $1-4$ semester & 93 & 53,44 \\
$5-8$ semester & 65 & 37.35 \\
$9-12$ semester & 15 & 8,62 \\
Lebih dari 12 semester & 1 & 0,57 \\
\hline
\end{tabular}

Sumber: data diolah 2016

Apabila dicermati dalam tabel 1 menunjukkan bahwa pemustaka berjenis kelamin wanita lebih daripada pria. Kondisi riil yang ada di Fakultas Psikologi UGM menunjukkan bahwa jumlah sivitas akademika berjenis kelamin wanita lebih banyak daripada pria (lihat Tabel 2). Oleh karena itu hasil kajian sesuai dengan kondisi yang ada di Fakultas Psikologi UGM.

Tabel 2

Jumlah sivitas akademika di lingkungan Fakultas Psikologi UGM tahun 2016 berdasarkan jenis kelamin

\begin{tabular}{lcc}
\hline \multicolumn{1}{c}{ Status } & Pria & Wanita \\
\hline Mahasiswa (S1, S2, S3) & $24,30 \%$ & $75,70 \%$ \\
\hline Tenaga Pendidik \& kependidikan & $43,40 \%$ & $56,60 \%$ \\
\hline Sumber: data diolah 2016 & &
\end{tabular}

Berdasarkan program studi menunjukkan bahwa pemustaka program studi sarjana lebih dari program studi yang lain, jumlahnya melebihi $50 \%$. Hal ini diasumsikan bahwa pemustaka program studi sarjana lebih banyak membutuhkan sumber infomasi dasar terkait dengan ilmu psikologi, di samping itu mereka masih banyak membutuhkan wawasan yang lebih luas di bidang tersebut. Berbeda dengan pemustaka dari program studi S2, mereka lebih fokus pada psikologi yang lebih spesifik dan diasumsikan kebutuhan mereka menjadi lebih spesifik pula. Dengan demikian mereka hanya membutuhkan sumber informasi yang lebih khusus. Pemustaka program studi S3 selama kajian berlangsung tidak ada yang menggunakan fasilitas 
perpustakaan, kondisi ini diasumsikan karena program studi S3 menyediakan ruang belajar khusus di luar perpustakaan.

Selama tiga bulan berlangsungnya pengambilan data di perpustakaan, data yang diperoleh menunjukkan bahwa pemustaka yang sudah menempuh studi dalam rentang 1-4 semester persentasenya paling tinggi, hal ini diasumsikan bahwa apabila dikaitkan dengan program studi S1 yang menduduki persentase tinggi menunjukkan bahwa mereka adalah mahasiswa baru yang masih membutuhkan dasar dan wawasan ilmu psikologi. Sementara pemustaka yang sudah menempuh studi dalam rentang 5-8 semester persentasenya berada pada tingkat di bawahnya, dan pemustaka yang sudah menempuh studi lebih dari sembilan semester persentasenya paling sedikit. Hal ini diasumsikan bahwa mereka berkunjung ke perpustakaan dalam rangka menyelesaikan atau menyusun tugas akhir.

\section{Kepuasan pemustaka terhadap fasilitas perpustakaan}

Seperti dikemukakan sebelumnya bahwa variabel kepuasan pemustaka terhadap fasilitas perpustakaan difokuskan pada lima indikator, yaitu: koleksi, layanan, teknologi informasi, sumber daya manusia, serta sarana prasarana.

\section{a. Kepuasan pemustaka terhadap koleksi}

Dalam hal ini kepuasan terhadap koleksi dijabarkan ke dalam sembilan butir pernyataan sebagai berkut: buku wajib, buku pengayaan, majalah ilmiah, tugas akhir dan penelitian, e-book, ejournal, kemutakhiran, relevansi, dan kondisi fisik. Hasil analisis disajikan dalam Tabel 3.

Tabel 3

Kepuasan pemustaka terhadap fasilitas koleksi

\begin{tabular}{lcc}
\hline \multicolumn{1}{c}{ Fasilitas koleksi } & $\begin{array}{c}\text { Nilai skor } \\
(\%)\end{array}$ & Kategori \\
\hline Buku wajib & 77,82 & Sangat Memuaskan \\
\hline Buku pengayaan & 73,56 & Memuaskan \\
\hline Majalah ilmiah & 73,22 & Memuaskan \\
\hline $\begin{array}{l}\text { Tugas akhir dan } \\
\text { penelitian }\end{array}$ & 78,39 & Sangat Memuaskan \\
\hline e-book & 70,34 & Memuaskan \\
\hline e-journal & 75,98 & Sangat Memuaskan \\
\hline Kemutakhiran & 69,89 & Memuaskan \\
\hline Relevansi & 74,94 & Sangat Memuaskan \\
\hline Kondisi fisik & 70,23 & Memuaskan \\
\hline \multicolumn{1}{c}{ Jumlah } & 664,4 & \\
\hline Sumb: data dian & &
\end{tabular}

Sumber: data diolah 2016
Berdasarkan tabel 3 skor rata-rata untuk kepuasan pemustaka terhadap koleksi sebesar $73,82 \%$, hal ini menunjukkan bahwa kepuasan pemustaka terhadap koleksi termasuk dalam kategori sangat memuaskan.

\section{b. Kepuasan pemustaka terhadap layanan}

Fasilitas layanan dalam kajian ini dijabarkan ke dalam tujuh pernyataan: proses layanan, jumlah jam layanan, koleksi dipinjam, waktu peminjaman, penelusuran, pinjam antar perpustakaan, sanksi keterlambatan. Hasil perhitungan selengkapnya disajikan dalam Tabel 4.

Tabel 4

Kepuasan pemustaka terhadap fasilitas layanan

\begin{tabular}{lcc}
\hline \multicolumn{1}{c}{ Fasilitas layanan } & $\begin{array}{c}\text { Nilai skor } \\
(\%)\end{array}$ & Kategori \\
\hline Proses layanan & 80,23 & Sangat Memuaskan \\
\hline Jumlah jam layanan & 70,11 & Memuaskan \\
\hline Koleksi dipinjam & 60,57 & Memuaskan \\
\hline Waktu peminjaman & 70,34 & Memuaskan \\
\hline Penelusuran & 73,22 & Memuaskan \\
\hline $\begin{array}{l}\text { Pinjam antar } \\
\text { perpustakaan }\end{array}$ & 66,78 & Memuaskan \\
\hline Sanksi keterlambatan & 72,41 & Memuaskan \\
\hline \multicolumn{1}{c}{ Jumlah } & 493,70 & \\
\hline
\end{tabular}

Sumber: data diolah 2016

Berdasarkan tabel 4 hasil perhitungan skor rata-rata untuk kepuasan pemustaka terhadap fasilitas layanan yang tersedia sebesar 70,52\%. Hal ini menunjukkan bahwa kepuasan pemustaka terhadap fasilitas layanan termasuk dalam kategori memuaskan.

\section{c. Kepuasan pemustaka terhadap fasilitas teknologi informasi}

Dalam kajian ini kepuasan pemustaka terhadap fasilitas teknologi informasi dijabarkan dalam delapan pernyataan. Hasil selengkapnya dapat dilihat pada Tabel 5.

Berdasarkan tabel 5 hasil perhitungan skor rata-rata untuk kepuasan pemustaka terhadap fasilitas teknologi informasi yang tersedia sebesar $69,77 \%$. Hal ini menunjukkan bahwa kepuasan pemustaka terhadap fasilitas teknologi informasi termasuk dalam kategori memuaskan. 
Tabel 5

Kepuasan pemustaka terhadap fasilitas teknologi informasi

\begin{tabular}{lcl}
\hline Fasilitas TI & $\begin{array}{c}\text { Nilai skor } \\
(\%)\end{array}$ & \multicolumn{1}{c}{ Kategori } \\
\hline $\begin{array}{l}\text { Komputer tersambung } \\
\text { internet }\end{array}$ & 76,32 & Sangat Memuaskan \\
\hline Komputer intranet & 76,21 & Sangat Memuaskan \\
\hline Kapasitas Wifi & 76,44 & Sangat Memuaskan \\
\hline $\begin{array}{l}\text { Kecepatan jaringan } \\
\text { internet }\end{array}$ & 73,10 & Memuaskan \\
\hline Sistem OPAC & 72,76 & Memuaskan \\
\hline Stop kontak & 41,38 & Kurang Memuaskan \\
\hline Akses dari rumah & 67,36 & Memuaskan \\
\hline $\begin{array}{l}\text { Peralaan TIK permudah } \\
\text { akses informasi }\end{array}$ & 74,60 & Sangat Memuaskan \\
\hline Jumlah & 558,2 & \\
\hline Sumber: data diolah 2016 & & \\
\hline
\end{tabular}

\section{d. Kepuasan pemustaka terhadap sumber daya manusia}

Kepuasan pemustaka terhadap sumber daya manusia dijabarkan ke dalam delapan pernyataan. Hasil selengkapnya disajikan dalam Tabel 6 berikut ini.

Tabel 6

Kepuasan pemustaka terhadap sumber daya manusia

\begin{tabular}{lcc}
\hline Sumber daya manusia & $\begin{array}{c}\text { Nilai skor } \\
(\%)\end{array}$ & Kategori \\
\hline $\begin{array}{l}\text { Petugas berpenampilan } \\
\text { menarik dan sopan }\end{array}$ & 82,18 & $\begin{array}{c}\text { Sangat } \\
\text { Memuaskan }\end{array}$ \\
\hline $\begin{array}{l}\text { Petugas memberi perhatian } \\
\text { kepada setiap pemustaka }\end{array}$ & 79,31 & $\begin{array}{c}\text { Sangat } \\
\text { Memuaskan }\end{array}$ \\
\hline $\begin{array}{l}\text { Petugas paham terhadap } \\
\text { kebutuhan dan keinginan } \\
\text { pemustaka }\end{array}$ & 77,13 & $\begin{array}{c}\text { Sangat } \\
\text { Memuaskan }\end{array}$ \\
\hline $\begin{array}{l}\text { Petugas membantu } \\
\text { pemustaka dengan senang } \\
\text { hati }\end{array}$ & 79,54 & $\begin{array}{c}\text { Sangat } \\
\text { Petugas membantu } \\
\text { pemustaka dengan penuh } \\
\text { perhatian }\end{array}$ \\
$\begin{array}{l}\text { Petugas terampil } \\
\text { menangani permasalahan }\end{array}$ & 78,85 & $\begin{array}{c}\text { Sangat } \\
\text { layanan yang dialami } \\
\text { pemustaka }\end{array}$ \\
\hline $\begin{array}{l}\text { Petugas berpengetahuan dan } \\
\text { mampu menjawab } \\
\text { pertanyaan pemustaka }\end{array}$ & 79,54 & $\begin{array}{c}\text { Sangat } \\
\text { Petugas siap menjawab } \\
\text { pertanyaan pemustaka }\end{array}$ \\
\hline Jumlah & 79,43 & Memuaskan \\
\hline $\begin{array}{l}\text { Sumber: data diolah } 2016 \\
\text { Memuaskan }\end{array}$ \\
\hline
\end{tabular}

Berdasarkan tabel 6 hasil perhitungan skor rata-rata untuk kepuasan pemustaka terhadap sumber daya manusia sebesar 79,37\%. Hal ini menunjukkan bahwa kepuasan pemustaka terhadap sumber daya manusia termasuk dalam kategori sangat memuaskan.

\section{e. Kepuasan pemustaka terhadap sarana sarana prasarana}

Kepuasan pemustaka terhadap sarana prasarana dijabarkan ke dalam sembilan pernyataan. Hasil selengkapnya disajikan dalam Tabel 7.

Tabel 7

Kepuasan pemustaka terhadap sarana prasarana

\begin{tabular}{lcc}
\hline Sarana Prasarana & $\begin{array}{c}\text { Nilai skor } \\
(\%)\end{array}$ & Kategori \\
\hline $\begin{array}{l}\text { Ruang perpustakaan } \\
\text { memotivasi untuk } \\
\text { belajar }\end{array}$ & 75,29 & Sangat Memuaskan \\
\hline Ketenangan & 81,61 & Sangat Memuaskan \\
\hline Kenyamanan & 81,03 & Sangat Memuaskan \\
\hline Disain tata ruang & 73,10 & Memuaskan \\
\hline Penerangan & 80,34 & Sangat Memuaskan \\
\hline Kebersihan & 85,52 & Sangat Memuaskan \\
\hline Meja dan kursi & 79,77 & Sangat Memuaskan \\
\hline AC (pendingin ruangan) & 71,15 & Memuaskan \\
\hline Locker & 77,82 & Sangat Memuaskan \\
\hline Jumlah & 705,6 & \\
\hline Sum: & &
\end{tabular}

Sumber: data diolah 2016

Berdasarkan tabel 7 hasil perhitungan skor rata-rata untuk kepuasan pemustaka terhadap sarana prasarana yang tersedia sebesar $78,40 \%$. Hal ini menunjukkan bahwa kepuasan pemustaka terhadap sarana prasarana termasuk dalam kategori sangat memuaskan.

Secara keseluruhan kepuasan pemustaka terhadap fasilitas perpustakaan disajikan dalam Tabel 8.

Tabel 8

Kepuasan pemustaka terhadap fasilitas perpustakaan

\begin{tabular}{lcl}
\hline \multicolumn{1}{c}{ Fasilitas } & $\begin{array}{c}\text { Nilai skor } \\
(\%)\end{array}$ & \multicolumn{1}{c}{ Kategori } \\
\hline Koleksi & 73,82 & Sangat Memuaskan \\
\hline Layanan & 70,52 & Memuaskan \\
\hline Teknologi Informasi & 69,77 & Memuaskan \\
\hline Sumber daya manusia & 79,37 & Sangat Memuaskan \\
\hline Sarana Prasarana & 78,40 & Sangat Memuaskan \\
\hline \multicolumn{1}{c}{ Jumlah } & 371,9 & \\
\hline
\end{tabular}

Sumber: data diolah 2016

Berdasarkan tabel 8 diperoleh skor rata-rata sebesar 74,38\% dan kondisi ini menunjukkan bahwa kepuasan pemustaka terhadap fasilitas perpustakaan di Fakultas Psikologi Universitas Gadjah Mada termasuk dalam kategori sangat memuaskan. 


\section{E. KESIMPULAN}

1. Kesimpulan

Berdasarkan hasil dan pembahasan dalam kajian ini dapat disimpulkan bahwa:

a. Pemustaka wanita lebih tinggi persentasenya $(79,88 \%)$ daripada pria $(20,12 \%)$, dan mahasiswa program studi sarjana persentasenya tertinggi $(64,94 \%)$ di antara program studi yang lain.-Mereka sebagian besar $(53,44 \%)$ sudah menempuh studi dalam rentang 1-4 semester.

b. Kepuasan terhadap fasilitas yang tersedia di perpustakaan Fakultas Psikologi UGM ratarata nilai skornya sebesar $74,38 \%$ termasuk dalam kategori sangat memuaskan. Ada tiga fasilitas termasuk dalam kategori sangat memuaskan yaitu koleksi, sumber daya manusia, dan sarana prasarana. Dua fasilitas yang lain hasilnya termasuk dalam kategori memuaskan. Rata-rata nilai skor fasilitas Teknologi Informasi persentasenya paling rendah, dan ada satu butir pernyataan dengan nilai skor rata-rata dalam kategori kurang memuaskan yaitu mengenai "stop kontak" yang tersedia di perpustakaan.

\section{Saran}

Beberapa saran yang diusulkan berdasarkan kesimpulan di atas dan saran dari beberapa responden, yaitu:

a. Penambahan stop kontak di dalam perpustakaan, mengingat hampir semua pengunjung perpustakaan membawa laptop pribadi.

b. Fasilitas komputer intranet yang masih terbatas jumlahnya perlu ada penambahan lagi. Komputer ini memfasilitasi pemustaka untuk membaca hasil-hasil penelitian maupun tugas akhir mahasiswa yang ada di lingkup Universitas Gadjah Mada. Selain penambahan komputer, perlu dipertimbangkan batas waktu pemakaian oleh setiap pemustaka, untuk memberi kesempatan kepada pemustaka yang lain.

c. Letak perpustakaan yang berada di lantai tiga, perlu disediakan fasilitas akses khusus bagi anggota difabel, agar mereka dapat menggunakan fasilitas yang tersedia di perpustakaan.

\section{DAFTAR PUSTAKA}

Arikunto, S. (2010). Prosedur penelitian: suatu pendekatan praktik. Jakarta: Rineka Cipta.

Badan Akreditasi Nasional Perguruan Tinggi. (2011). Akreditas institusi perguruan tinggi. Buku V Pedoman penilain borang dan evaluasi diri AIPT. Diunduh dari http://aipt.polsri.ac.id/buku\%20naskah/ 5\%20BUKU\%205\% 20 PEDOMAN\%20 PENILAIAN\%20BORANG\%20DAN\%20 EVALUASI\%20DIRI\%20AIPT\%202011.p df

Deo, S.(2016). An Assessment of user satisfaction in academic libraries: a case study at the Fiji National University. Diunduh dari https: // papers. ssrn.com/sol3/ papers.cfm? abstract_id $=2805283$.

Dharma, N.O. (2013). Hubungan antara kualitas layanan perpustakaan Undiksha dan kepuasan penggunanya. Jurnal Ilmu Sosial dan Humaniora. 2 (2), 222-238.

Ezeala, LO. And Yusuff, EO. (2011). User satisfaction with library resources and service in Nigerian Agricultural Research Institute. Diunduh dari: Library Philosophy and Practice. https://www.webpages.uidaho.edu/ $\sim$ mbolin/ ezeala-yusuff.pdf.

Fakultas Psikologi UGM. (2016). Laporan Akhir Dekan Fakultas Psikologi, 6 Oktober 2016. Yogyakarta: Fakultas Psikologi UGM.

Firman, A. dan Rahmah, E. (2012). Faktor-faktor yang mempengaruhi kepuasan pemustaka di Perpustakaan Kopertis Wilayah X. Jurnal Ilmu Informasi Perpustakaan dan Kearsipan. 1 (1) Seri B: 110-115.

Hadi, S. (2002). Metodologi Research Jilid 1. Yogyakarta: Andi.

Kotler, P. (2000). Marketing management: analysis, planning, implementation and control. New Jersey: Prentice Hall.

Larson, GA. And Owusu-Acheaw, M. (2012). Undergraduate students satisfaction with library services in a faculty pibrary in University of Education Winneba, Ghana. Library Philosophy and Practice Journal (ejournal). Diunduh dari: https:// www.researchgate.net/publication/28004868 8 Undergraduate_Students_Satisfaction With_Library_Services_in_A_Faculty_ Library_in_University_of $\bar{f}_{-}$Education Winneba_Ghana 
Maryadi dan Widodo, W. (2010). Strategi perguruan tinggi dalam upaya meningkatkan kualitas sumber daya manusia. Majalah Ilmiah Lontar, 24(2), 27-36.

Nursiah. (2008). Analisis pengaruh kualitas pelayanan terhadap kepuasan mahasiswa pengguna Perpustakaan Politekik Negeri Medan. Jurnal Polimedia, Vol. 11, No. 3. Diunduh dari http://id.portalgaruda.org/ ? $\mathrm{ref}=$ browse $\& \bmod =$ viewarticle $\&$ article $=$ 48089.

Perpustakaan Nasional RI. (2011). SNI. Standar Nasional Indonesia bidang Perpustakaan dan Kepustakawanan. Jakarta: Perpustakaan Nasional.

Rahayuningsih. (2015). Survei peningkatan mutu berkelanjutan melalui pemantauan dan pengukuran kepuasan pemustaka. Berkala Ilmu Perpustakaan dan Informasi. XI (2), 1623.
Sulistyo-Basuki. (1991). Pengantar Ilmu Perpustakaan. Jakarta: Gramedia Pustaka Utama.

Snyder, CR. and Lopez, SJ. (2007). Positive psychology. The scientific and practical exploration of human strength. Thousand Oaks: Sage Publication.

Sutarno. (2005). Tanggung jawab perpustakaan dalam mengembangkan masyarakat informasi. Jakarta: Panta Rei.

Tjiptono, F. (1997). Strategi pemasaran. Yogyakarta: Andi Offset.

Wijaya, NMCS. (2015). Evaluasi kepuasan pengguna terhadap pelayanan di Perpustakaan Umum Daerah Tabanan. Jurnal Ilmiah D3 Perpustakaan, 1 (1) Diunduh dari http://id.portalgaruda.org/?ref=browse\&mod $=$ viewarticle $\&$ article $=337460$. 